\title{
GENEALOGI SPRITUAL TAREKAT NAQSYABANDIYAH KHALIDIYAH DI MINANGKABAU BERDASARKAN NASKAH IJAZAH SERTA KARAKTERISTIK IJAZAHNYA
}

\author{
Chairullah \\ (Alumni Fakultas Adab IAIN Imam Bonjol Padang. Email: chairullah.ahmad@yahoo.co.id
}

\begin{abstract}
Tarekat Naqsyabandiyah Khalidiyah merupakan salah satu tarekat muktabarah yang memiliki banyak pengikutnya di Indonesia. Tarekat Naqsyabandiyah Khalidiyah juga merupakan tarekat yang mendominasi wilayah Minangkabau. Dalam pandangan sejarawan dan peneliti seperti Schrieke dan Martin van Bruinessen tarekat Naqsyabandiyah mulai berkembang di Minangkabau pada pertengahan abad ke 19 yaitu tahun 1850 M oleh Syekh Ismail Simabur. Berbeda dengan Schrieke dan Bruinessen, Azra dan Dobbin berpendapat bahwa tarekat Naqsyabandiyah telah berkembang di Minangkabau pada pertengahan abad ke $17 \mathrm{M}$ oleh Jamaluddin. Namun berdasarkan sumber lokal yang ditemukan berupa Naskah Ijazah dan Silsilah ditemukan fakta lain yaitu tarekat Naqsyabandiyah telah berkembang di Minangkabau pada awal abad ke 19. Artikel ini bertujuan untuk menjelaskan genealogi Spritual tarekat Naqsyabandiyah di Minangkabau berdasarkan naskah ijazah, serta melihat karakteristik dari ijazah tarekat Naqsyabandiyah yang berkembang di Minangkabau.
\end{abstract}

Kata Kunci: Genealogi, Tarekat Naqsyabandiyah, Naskah Ijazah,

\section{PENDAHULUAN}

Sejarah masuk dan berkembangnya tarekat Naqsyabandiyah di Minangkabau masih menjadi perbedaan pendapat di kalangan ahli sejarah dan peneliti seperti Martin van Bruinessen, Schrieke, Christine Dobbin dan Azyumardi Azra. Menurut pendapat Bruinessen, tarekat Naqsyabandiyah telah berkembang di Minangkabau pada tahun 1850 M oleh Syekh Ismail (Bruinessen, 1992). Pendapat yang sama juga dijelaskan oleh Schrieke, bahwa tarekat Naqsyabandiyah berkembang di Minangkabau pada tahun $1850 \mathrm{M}$ dan mursyid pertamanya di Minangkabau ialah Syekh Ismail (Schrieke, 1973). Sedangkan menurut Azra dan Dobbin bahwa, tarekat Naqsyabandiyah telah berkembang di Minangkabau pada pertengahan abad ke-17 $\mathrm{M}$ yang dikembangkan oleh Jamaluddin. Ia mula-mula belajar di Pasai dan kemudian melanjutkannya ke Bayt al-
Faqi, Aden, Harmayn, Mesir dan India. Dalam perjalanan pulangnya ia berhenti di Aceh sebelum melanjutkannya ke Sumatera Barat. Di Aceh ia aktif mengajarkan dan menyebarkan tarekat Naqsyabandiyah. Jamaluddin juga memiliki sebuah karya yang berjudul Lubab al-Hidayah, karya ini disandarkan kepada ajaran-ajaran Ahmad 'Ibnu 'Alan al-Shiddiqi al-Naqsyabandiyah (Azra, 2007).

Pendapat Schireke dan Bruinessen di atas didukung oleh penelitian tebaru tentang Naqsyabandiyah Khalidiyah di Minangkabu yang ditulis oleh Syofyan Hadi. Ia berpendapat bahwa tarekat Naqsyabandiyah berkembang pada awal abad 19 M melalui kawasan Pantai Timur Sumatera Barat atas pengaruh dan jasa Syeikh Ismail. Pendapat ini bersumber dari hasil penelitiannya terhadap naskah al-Manhal al'adhb li-dhikir al-qalb yang ia anggap karya Syekh 
Ismail yang ditulis di Riau pada tahun $1829 \mathrm{M}$. Berdasarkan temuannya itu, Hadi berkesimpulan bahwa Syekh Ismail telah berada di Riau dan mengembangkan ajaran tarekat Naqsyabandiyah di sana pada tahun 1829 M (Hadi, 2011). Jika merujuk kepada naskah al-Manhal al-'adhb li-dhikir al-qalb" tidak akan ditemukan angka tahun penulisannya, akan tetapi tahun itu disembunyikan dalam bait nazam yang ditulis yaitu :

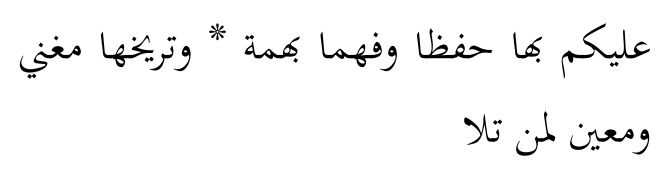

Lazimkan olehmu dengan dia itu mempahamkan dengan himmah * dan tarikhnya itu mengikuti lagi menolong bagi siapa-siapa membaca akan dia

$$
\begin{aligned}
& \text { بيوم ثلوث أطيب العيد في ريو * بيت سلوك } \\
& \text { نظمها قد تكملا نول }
\end{aligned}
$$

Pada hari selasa sebaik-baik hari ia fitrah di dalam negeri Riau

* di dalam rumah suluk nazamnya sungguhnya telah sempurna (Hadi, 2011).

Meskipun demikian, pendapat ini perlu dikritisi berdasarkan dua hal. Pertama, pada nazam di atas terdapat kalimat مغني ومعين yang merupakan simbol dari angka tahun penulisan naskah, jika kita hitung dengan menggunakan metode Hisab al-Jumal maka huruf itu berjumlah 1276 (Dipodjojo, 1996). Jadi, naskah ini sebenarnya ditulis pada tahun $1276 / 1858 \mathrm{M}$ setahun setelah Syekh Ismail wafat. Kedua, Syekh Ismail pertama kali diundang ke Riau untuk mengajarkan ilmu agama oleh Raja Ali bin Yamatuan Muda Raja Ja'far yang ketika itu menjadi Yamatuan Muda Riau VIII menggantikan saudara kandungnya Raja Abdurrahman Yamatuan Muda Riau VII yang mangkat pada 17 Juni 1844 M (Abdullah, 1985), sehingga hal ini tidak mungkin Syekh Ismail berada di Riau pada tahun $1829 \mathrm{M}$.

Jika dipelajari lebih dalam perbedaan pendapat di atas antara Schrieke, Bruinessen dengan Azra dan Dobbin, dapat diketahui perbedaan pendapat itu terjadi karena objek yang berbeda. Meskipun objeknya adalah tarekat Naqsyabandiyah, namun kenyataannya tarekat Naqsyabandiyah sangatlah banyak. Pada awalnya tarekat ini bernama Siddiqiyah yang dinisbahkan kepada Abu Bakar as-Shiddiq, kemudian penamaannya berubah menjadi Thaifuriyah, setelah itu Khaujakaniyah, setelah itu Naqsyabandiyah, setelah itu Naqsyabandiyah Abrariyah, setelah itu Naqsyabandiyah Mujaddidiyah dan Muzhahiriyah, dan terakhir pada masa Syekh Khalid Kurdi dinamai dengan Naqsyabandiyah Khalidiyah yang dinisbahkan kepada Syekh Khalid Kurdi (Dausari, 1306H: 84). Sangat terlihat jelas bahwa Naqsyabandiyah yang dimaksud Azra dan Dobbin adalah Naqsyabandiyah Mujaddidiyah. Bukan Naqsyabandiyah Khalidiyah seperti yang dimaksud oleh Schrieke dan Dobbin, karena Naqsyabandiyah Khalidiyah baru ada pada awal abad $19 \mathrm{M}$.

Penelitian ini menggunakan dua pendekatan, pertama filologi untuk membaca sumber-sumber manuskrip yang nantinya akan disunting dengan menggunakan edisi kritis, yaitu hasil olah penyunting yang menginginkan terbentuknya sebuah teks dengan kualitas bacaan terbaik (Fathurahman, 2011). Kedua pendekatan historis untuk menganalisi dan mengkontektualisasikan naskah ijazah yang akan digunakan sebagai sumber utama penelitian ini. 
MEMBACA GENEALOGI TAREKAT NAQSYABANDIYAH KHALIDIYAH DI MINANGKABAU

Tarekat Naqsyabandiyah telah masuk ke Minangkabau pada akhir abad ke 18 M. Pada akhir abad $18 \mathrm{M}$ ini, muncul beberapa nama tokoh ulama di Minangkabau yang dianggap penganut tarekat Naqsyabandiyah, diantaranya: Syekh Jalaluddin Cangkiang, Syekh Daud Sunur dan Syekh Sa’ad Padang Bubuih. Syekh Jalaluddin sebelum menganut Naqsyabandi, adalah seorang ulama penganut Syattariyah. Syekh Jalaluddin adalah murid terbaik dari Tuanku nan Tuo, seorang guru tarekat Shattariyah yang memiliki pengaruh besar di daerah Koto Tuo Ampek Angkek (Dobbin, 2008). Tidak ada keterangan di mana dan dari siapa Syekh Jalaludin membai'at masuk tarekat Naqsyabandiyah, namun di Cangking ia mengajarkan tarekat Naqsyabandiyah bukan Syattariyah. Hal ini dapat dilihat dalam keterangan yang diberikan oleh Imam Maulana 'Abdul Manaf:

\begin{abstract}
"Waktu itu seluruh Minangkabau satu mazhab yaitu mazhab Imam Syafi'I, satu itikad yaitu itikad ablulsunah waljamaiah, satu tasawufyaitu atas tarekat Syattariah dan satu bilangan bulan yaitu hisab taqwim dan satu cara memasuki puasa yaitu dengan ru'yah alhilal. Artinya melihat bulan di malam ketiga puluh tidak ada pertikaiannya. Kemudian pada tahun 1207 Hijriah duduklah mengajar di Kampung Cangkiang Koto Tuo Canduang Empat Angkat Bukittinggi seorang ulama yang dimasyhurkan orang dengan Tuan Syaikh Koto Tuo (Tuan Syaikh Cangkiang) yang mengajarkan agama Islam yang bermazhab Imam Syafi'i dan beritikad ablussunah waljama'ah. Tetapi dalam tasawuf atas tarekat Naqsyabandi dan untuk memasuki puasa memakai bilangan lima tidak memakai rukyah. Hanya melihat bintang pagi diakhir bulan." (manuskrip Taqwim as-Shiyam)
\end{abstract}

Meskipun demikian, tidak ada keterangan yang jelas dan lengkap tentang kesinambungan perkembangan tarekat Naqsyabandiyah yang ia kembangkan di Minangkabau. Syekh Jalaluddin memiliki banyak murid-murid, di antaranya yang cukup terkenal ialah Syekh Daud Sunur. Syekh Daud Sunur adalah seorang ulama muda yang begitu gigih menuntut ilmu. Setelah belajar dengan Syekh Cangkiang, ia mendakwahkan sesuatu yang baru di Sunur kampung halamannya, sehingga ia memiliki banyak pengikut dan diberi panggilan Syekh. Namun aktifitasnya itu dihalangai oleh salah seorang ulama Syattariyah terkemuka di Lubuk Ipuah, ia dikenal dengan Syekh Lubuk Ipuah. Hingga, pada tahun 1820 M Syekh Daud dan Syekh Lubuk Ipuah berdebat hebat, Syekh Daud pun menerima kekalahan dari perdebatan itu dan dipermalukan di depan orang banyak. Karena merasa malu, ia meninggalkan kampung halamannya dan pergi ke Mekkah (Suryadi, 2005). Ketika di Mekkah, Syekh Daud bertemu dengan Syekh Ismail Simabur dan memandu Syekh Ismail dalam beberapa hal. Beberapa lama setelah itu tepatnya tahun 1830 M Syekh Ismail membantu mengedit syair yang ditulis Syekh Daud, syair itu ditujukan untuk menentang ajaran Syekh Lubuak Ipuah (Laffan, 2002). Setelah beberapa lama bermukim di Mekkah Syekh Daud melanjutkan perjalanannya ke Trumo Aceh dan menjadi guru Raja Bujang hingga Syekh Daud wafat di sana(Suryadi, 2005).

Tarekat Naqsyabandiyah baru mencapai masa kejayaannya di Minangkabau pada awal abad $19 \mathrm{M}$ yang dikembangkan oleh Syekh Ibrahim Kumpulan dan murid-murid Syekh Ismail Minangkabawi setelah pulang dari Mekkah. Tarekat ini memiliki banyak pengikut di Minangkabau. Bahkan, pada abad 19 M tarekat Naqsyabandiyah lebih dominan 
di Minangkabau dibanding tarekat Syattariyah. Tarekat ini berkembang pesat ke berbagai pelosok di Minangkabau. Begitu banyak ulama-ulama yang menganut dan mengajarkan tarekat ini, namun yang sangat berjasa dalam perkembangannya di Minangkabau adalah Syekh Ibrahim Kumpulan, Syekh Ismail al-Minangkabawi lewat muridnya Syekh Muhammad Thaher Barulak dan Syekh Abdurrahman. Berkat jasa dan pengaruh mereka inilah tarekat Naqsyabandiyah berkembang pesat dan memiliki banyak pengikut di Minangkabau.

Mengenai transmisi intelektual tarekat Naqsyabandiyah Khalidiyah di Minangkabau masih menjadi suatu hal yang belum tuntas dikalangan peneliti. Banyak dari para peneliti yang berbeda dalam menguraikan genealogi tarekat Naqsyabandiyah di Minangkabau, hal ini disebabkan dari data yang mereka peroleh sehingga terjadi misleading. Sejauh ini, genealogi yang dipaparkan oleh para peneliti hanya berdasarkan informasi lisan atau reformulasi dari data peneliti sebelumnya. Hal ini mungkin disebabkan tidak ditemukannya titik dari sentra tarekat Naqsyabandiyah di Minangkabau.

Penamaan tarekat Naqsyabandiyah mulai dikenal pada masa Syekh Muhammad ibn Baha' al-Din al-Uwaisi al-ukhari atau yang dikenal dengan sebutan Shah Naqsyabandi (717-791 H/ 1318-1389 M). Ketika berusia 18 tahun Syekh Baha' al-Din mempelajari tasawuf kepada Baba al-Sammasi, kemudian melanjutkan pelajarannya kepada khalifah dari Syekh Baba al-Simmasi seorang kutub di Nafs yaitu Amir Sayyid Kulal (772 H/1371) (al-Nabhani, 1978). Dari Sayyid Kulal inilah ia belajar dasar-dasar tarekat yang kemudian ia dirikan yaitu Naqsyabandiyah
(Mulyati, 2004). Pada masa Syekh Mahmud al-Anjiri Faghnawi hingga zaman Sayyid Kulal mereka semua mengamalkan zikir Jahr ketika berhimpun bersama dan ketika dalam keadaan sendiri-sendiri mereka mengamalkan zikir Khafi. Ketika Syekh Baha' al-Din bertalaqi dengan tarekat ini ia menyederhanakannya dengan hanya mengamalkan zikir khafi (Amin al-Kurdi, 1996). Syekh Baha' al-Din mengangkat tiga orang khalifah utama yaitu Ya'qub al-Jarkhi (W. 838 H /1434 M), 'Ala al-Din 'Atthar (W.802 H /1400 M) dan Muhammad Parsa. Dari Yáqub al-Jarkhi sendiri mengangkat seorang khalifah yaitu 'Ubaydillah al-Ahrar (w.1490) yang telah menetapkan pola hubungan akrab dengan istana, yang kemudian hari diikuti Syekh-Syekh Naqsyabandi. Syekh 'Ubaydillah sangat dekat dengan penguasa Dinasti Timurid di Heart, Afghanistan yaitu Abu Sa’id. Berkat hubungannya ini Naqsyabandiyah berkembang ke luar Asia Tengah, antara lain ke Qazwin, Isfahan, dan Tabriz di Iran, dan ke Istanbul (Tim UIN Syarif Hidayatullah, 2008).

Ajaran tarekat Naqsyabandiyah juga menyebar ke India setelah Negri itu ditaklukan oleh Babur, pendiri kekaisaran Mughol, pada 1526 M. Di antara Syekh Naqsyabandi yang datang ke India adalah Muhammad Baqi Billah (W. $1014 \mathrm{H}$ ) dan tinggal di sana selama empat tahun. Selama empat tahun di Delhi Muhammad Baqi Billah mengangkat empat orang khalifah, dua diantaranya adalah Ahmad al-Faruqi Sirhindi (W. 1034 H) dan Taj al-Din Zakariya. Namun yang dianggap sebagai penerus resmi Muhammad Baqi Billah pada khanaqanya adalah Ahmad al-Faruqi (Bruinessen, 1992). Ahmad al-Faruqi Sirhindi mendapat gelar Mujaddid Alf al-Tsani 
karena ia dikenal sebagai sosok ulama pembaharu pada zamannya. Ia seorang sufi yang gigih dalam memperjuangkan syari'at dan kembali memurnikan setiap paham yang melenceng di zamannya seperti mengkritik kaum kafir, bid'ah dan berbagai doktrin yang salah, serta mengukuhkan kembali Nubuwwah yang pada masanya tidak diakui sebahagian besar orang (Ansari, 1986). Sebelum membai'at masuk kedalam tarekat Naqsyabandiyah, ia terlebih dahulu telah membai'at tarekat Qadiriyah dan Jistiyah dari ayahnya Syekh 'Abd al-Ahad dan mendapat ijazah kedua tarekat ini (Murad, 2002).

Setelah ayahnya wafat pada tahun 1597 M, Sirhindi menunaikan Ibadah haji. Dalam perjalanannya, di Delhi ia bertemu dengan Baqi Billah yang merupakan ulama Naqsyabandiyah pertama yang baru tiba di India. Baqi Billah namanya sudah cukup terkenal setelah baru beberapa bulan tinggal. Ia meminta Sirhindi untuk meluangkan waktunya beberapa hari saja, dalam perkenalan beberapa hari itu Sirhindi merasa tertarik dan membai'at masuk kedalam tarekat Naqsyabandiyah. Dalam waktu dua bulan setengah Sirhindi mendapat nisbah Naqsyabandiyah. Baqi Billah sangat terkejut dengan prestasi luar biasa yang dicapai oleh Sirhindi, ketakjuban itu diutarakan Baqi Billah lewat sebuah surat kepada sahabatnya (Hasan, 1333). Setelah wafatnya Baqi Billah, Sirhindi mengemban amanah yang berat sebagai seorang pengganti Baqi Billah. Tugas pertama yang dibebankan oleh dirinya sendiri adalah mempopulerkan tarekat Naqsyabandiyah (Ansari, 1986). Pada masa inilah ia mulai gigih untuk melakukan pembaharuan, khususnya beberapa bagian tertentu dalam tarekat, yang paling kontriversial adalah penolakannya terhadap wahdah al-wujud meskipun para ulama Naqsyabandiyah dari Asia Tengah, seperti kebanyakan kaum sufi pada masa itu mendukung wahdah al-wujud. Hal ini membuat Tajudin Zakariya seorang khalifah Baqi Billah lainnya yang mendukung wahdah al-wujud dengan kecewa meninggalkan Delhi dan berpindah ke Makah dan menetap di sana (Bruinessen, 1922). Sirhindi kemudian mengangkat putranya Muhammad Ma’shum (1007 H-1099 H) menjadi khalifahnya, kemudian Muhammad Ma’shum juga menunjuk putranya yaitu Syekh Muhammad Sayf al-Din al-Faruqi $(1055 \mathrm{H})$ untuk menggantikannya, kemudian Syekh Muhammad Syaf al-Din mengangkat seorang khalifah yang bernama Syekh Muhammad al-Badwani (W. $1135 \mathrm{H}$ ), kemudian Syekh Muhammad al-Badwani mengangkat seorang khalifah yang bernama Syekh Shamsudin Jan Janan (113 H), kemudian Syekh Shamsudn mengangkat seorang khalifah yang bernama Syekh 'Abdullah Dahlawi, kemudian Syekh 'Abdullah al-Dahlawi menganggkat seorang khalifah yaitu Syekh Diya' al-Din yang dikenal dengan Maulana Khalid Kurdi. Dimasa Syekh Khalid inilah tarekat Naqsyabandiyah berkembang pesat ke berbagai penjuru.

Syekh Khalid membai'at masuk tarekat Naqsyabandiyah dan menjalankan spritualnya di Delhi dibawah bimbingan Syekh 'Abdullah Dahlawi, pertemuannya dengan Syekh 'Abdullah tidak terjadi begitu saja, Syekh Khalid sebelumnya telah mendapat isarat dari seseorang yang ia temui ketika melaksanakan Haji di Mekkah (al-Damsyiqi, 1993). Ketika Syekh Khalid dibawah bimbingan Syekh 'Abdullah, tidak hanya tarekat Naqsyabandiyah yang ia pelajari, ia juga membai' at masuk kedalam empat tarekat lainnya 
dan mendapat ijazah yaitu tarekat Qadiriyah, Sahruwardiyah, Kubrawiyah, dan Jistiyah. Setelah mendapat ijazah dari Syekh 'Abdullah sebagai khalifahnya untuk daerah Kurdistan dan Irak, Syekh Khalid dikirim pulang ke negerinya. Syekh Khalid mengajarkan tarekat Naqsyabandiyah selama enam belas tahun. Ia juga dikenal sebagai seorang mujadid dalam tarekat Naqsyabandiyah, karena menambahkan metode suluk dalam tarekat ini yang sebelumnya tidak mengenal suluk (Amin al-Kurdi, t.th). Sebagai seorang Syekh tarekat, Syekh Khalid memiliki tujuan dan cita-cita yang tinggi untuk menyadarkan orang-orang muslim yang terjebak dengan dunia dan mengabaikan akhiratnya kepada jalan yang lurus, hal ini yang membuat dirinya menjadi sosok ulama kharismatik (Foley, 2008).

Salah seorang khalifahnya yang ia utus ke Mekah adalah 'Abdullah Afandy. 'Abdullah Afandy kemudian mendirikan Zawiyah di Jabal Abi Qubais, dari sanalah kemudian tarekat Naqsyabandiyah menyebar ke Nusantara yang dibawa oleh ulama-ulama Jawi yang belajar di Mekah. Diantara khalifah Syekh 'Abdullah Afandy, ada dua orang yang berasal dari Minangkabau yaitu Syekh Ismail dan Syekh 'Abd al-Wahab bin Fahati atau yang lebih dikenal dengan Syekh Ibrahim Kumpulan. Untuk menggantikan posisinya di Jabal Qubais Syekh 'Abd Allah Afandy kemudian mengangkat Sulayman al-Qarimi sebagai khalifahnya. Syekh Sulayman al-Qarimi kemudian mengangkat seorang khalifah untuk menggantikannya yaitu Syekh Sulayman Zuhdi.

Selama menjadi mursyid tarekat Naqsyabandiyah di Jabal Abi Qubais, Syekh Sulayman Zuhdi memeiliki pengaruh besar terhadap murid-murid asal Turki dan Nusantara. Pada masanya Syekh Sulayman Zuhdi banyak mengeluarkan ijazah-ijazah bagi para murid asal Indonesia (Bruinessen, 1995). Buktinya banyak sekali ulama-ulama tarekat Naqsyabandiyah di Minangkabau yang juga mendapatkan ijazah dari Syekh Sulayman Zuhdi. Syekh Sulayman Zuhdi juga memainkan peranan yang besar atas perkembangan tarekat Naqsyabandiyah di Minangkabau setelah pertengahan hingga akhir abad ke $19 \mathrm{M}$.

\section{MENGUAK KARAKTERISTIK NASKAH IJAZAH DAN SILSILAH TAREKAT NAQSYABANDIYAH DI MINANGKABAU}

Naskah menjadi salah satu sumber primer yang otentik dan dapat mendekati jarak antara masa lalu dan masa sekarang (Fathurahman, 2011). Oleh sebab itu naskah menjadi sumber yang sangat penting untuk kajian sejarah, seperti Naskah Ijazah dan Silsilah yang berisikan tentang pemberian ijazah seorang mursyid (guru spritual) kepada seorang murid yang dianggap teleh layak untuk meneruskan pengajran yang diberikan oleh sang mursyid kepada orang lain.

Istilah ijazah berasal dari bahasa arab إجازة yang berbentuk mashdar, dari lafaz أجاز yang berasal dari fíil madi mujarrad جاز yang berarti أفعل boleh. Kemudian dialihkan ke wazan dengan menambahkan hamzah yang berfungsi menjadikan fíl lazim menjadi muta'addi. Jadi, ijâzah mempunyai arti memperbolehkan atau memberi izin. Dalam dunia pesantren, ijazah diartikan sebagai pemberian izin oleh guru yang telah memiliki sanad sampai pada musannif sebuah kitab atau wirid dan amalan tertentu 
kepada seorang murid untuk meriwayatkan dan mengamalkannya (Forum Karya Ilmiyah (FKI) TAHTA Lirboyo, 2013).

Secara mendasar tidak ada perbedaan fungsi ijazah dalam tradisi tarekat Naqsyabandiyah dengan ijazah-ijazah dalam dunia pesantren, yaitu sebagai bukti bahwa seorang murid boleh menyampaikan dan mengamalkan apa yang telah dipelajarinya dari guru yang memberikannya ijazah. Bedanya, dalam tarekat Naqsyabandiyah para murid yang menjalankan spritualnya dengan cara bersuluk belum tentu akan mencapai maqam irsyâd. Sampai atau tidaknya sang murid kepada maqam irsyâd hanya diketahui oleh mursyid yang membimbingnya. Mursyid akan selalu memantau dan memperhatikan setiap kejadian yang dilalui oleh murid-muridnya selama $\varepsilon$. hari ketika suluk, dan bagi murid yang telah mencapai makam irsyâd, maka ia akan diberikan ijazah. Ketika seorang murid telah mendapatkan ijazah, secara tidak langsung murid telah berhak untuk mengajarkan teknik spritual yang dipelajarinya kepada orang lain. Melihat dinamika perkembangan tarekat di Minangkabau, terdapat beberapa tarekat yang pernah berkembang dan menancapkan pengaruhnya di Minangkabau seperti: Syattariyah, Naqsyabandiyah Khalidiyah, Syaziliyah, Qadiriyah dan Samaniyah. Sejauh penelitian yang dilakukan, hanya tarekat Naqsyabandiyah yang memiliki tradisi pengijazahan secara tertulis. Sedangkan tarekat lainnya hanya dijumpai silsilahnya saja, itu pun ditulis pada pertengahan abad $20 \mathrm{M}$.

Ijazah dalam tarekat Naqsyabandiyah merupakan sebuah bentuk legalitas bagi seorang mursyid untuk mengajarkan ajaran tarekat Naqsyabandiyah. Jika seseorang yang mengajarkan ajaran tarekat Naqsyabandiyah tetapi tidak memiliki izin mengajarkannya dalam bentuk ijazah, biasanya ajaran orang tersebut tidak diakui dan akan diketahui dan dikritik oleh mursyid tarekat yang sah yang memiliki ijazah. Keberadaan ijazah dalam tarekat Naqsyabandiyah memiliki peranan yang sangat penting, yaitu sebagai legalitas bagi seorang mursyid yang akan mengajarkan tarekat. Hal ini bertujuan untuk menghindari klaim-klaim dari seseorang yang mengaku telah berhak mengajarkan tarekat Naqsyabandiyah dan menyesatkan para jama'ah yang mengikutinya. Bukti sebuah ijazah memainkan peranan penting dalam tarekat Naqsyabandiyah adalah munculnya para agen penjual ijazah palsu dan orangorang yang mengaku sebagai mursyid tarekat Naqsyabandiyah. Kasus ini pernah terjadi di Minangkabau seperti: Barangkali saudara ada mendengar kejadian di Tanjung Alam Tabek Patah. Yaitu ada datang kesana seorang guru tarekat, menurut dakwanya dia ada membawa surat ijazah dan gambar dirinya sendiri, kemudian dipaksanya seorang penduduk Tanjung Alam tersebut untuk membeli surat ijazah itu dengan harga $\mathrm{Rp} 30$ dan gambar guru itu sendiri seharga Rp 1 akan tetapi orang yang dipaksakan itu meminta janji karena tidak ada punya uang dan bagaimana kesudahannya sampai sekarang tidaklah diketahui lagi wallâhu a’lam bi al-shawâb. Ada juga kami bertemu dengan seorang agen surat ijazah berjalan keliling kian kemari menawarnawarkan siapa yang akan membawa surat ijazah, maka disini kami percaya bahasa surat ijazah itu penting bagi orang yang hendak uang, sekali lagi hendak uang, dan memang tidak penting bagi orang yang hendak pahala akhirat (ar-Rasuly, 1954). 
Berdasarkan naskah ijazah yang ditemui dibeberapa skriptorium di Minangkabau, maka akan dijumpai tiga karakteristik ijazah dalam tarekat Naqsyabandia; pertama, ijazah yang hanya berisikan nama pemberi ijazah dan orang yang memberikan ijazah diiringi dengan wasiat tanpa menyebutkan sanad atau silsilah tarekatnya. Seperti :

$$
\text { بسم الله الرحمن الرحيم }
$$

الحمد لله حمدا يرتضيه لجنابه والصلوة والسلام على أجل من اصطفى لوحيه وخطابه خليفة

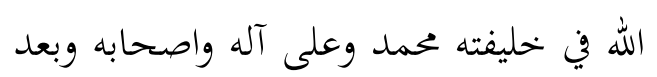
فأنا الفقير عبدالرحمن بن عبد الله الخالدي النقشبندي المقيم في حجر المفرش قد أجزت ولدي في الله والمحب لوجه الله السالك إلى الله أعنى به الحاج محمد راشدين بن مولنا عبد الرحمن الجاوي الباة همفاري وفقه الله تعالى يحبه ويرضاه وأسبغ على المؤمنين فيوضه ونواله بتلقين الذكر والتوجه المعهودة في الطريقة العلية النقشبندية المحلّددية المنسوبة إلى مظهر العجائب ومنبع الأسرار والمعاني شيخ المشائخ الشيخ أحمد الفاروقي السرهندي المعروف بالإمام الرباني المحدد الألف الثاني قدّس سرّه وجعلت يده يدي وقبوله قبولي فاضمن لكل من يلازم طريقة أن ينال ما لا يحيط به عقل العقلآ ويقصر عند فئه

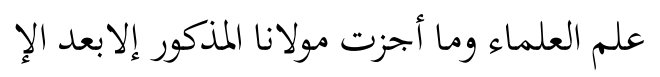
ستجازة من السادات المشهورة المذكورة أساميهم في السلسلة العلية المحددية والإستخارة الشرعية النبوية فليغتنم صحبته من يريد التثبت بهذه
الطريقة العلية والسنة السنية وأوصيه بالتمسك بالكتاب و السنة وآخره بتصحيح العقائده بمقتضى اراء أهل السنة الذين هم الفرق الناجية على ماأطبق عليه أئمة الكشف والوجدان وأوصيه بتوقير الفقهاء والفقرآ وحملة القرآن وبسلامة الصدر وسماحة النفس وسخاوة اليد ولبشسة الوجه بذل الندى والصفح عن عثرات الإخوان ونصيحة للأصاغر والأكابر وترك الخصومات وترك الطمع والإعتماد في قضاء الحوائج إلى الله جلّ جلّاله فإنه لايضيع من إلهن عول عليه وأن لايرجو النجاة إلا في الصدق ولا لإله

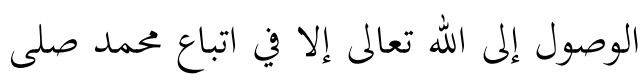
الله عليه وسلم وعلى آله وأصحابه وان لايظن أنه أفضل من أحد بل لايرى لنفسه وجود أو وعلى وله واصحابه واله

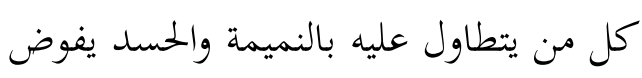
أمره إلى الله ولايتكلف في دفع شره بالهمة فإن من مشايخ هذه الطريقة العلية رجالا يتدكدك

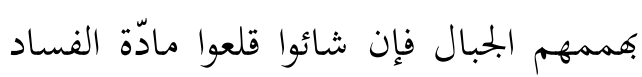
بقدرة الله تعالى في أسرع مايكون صلى الله على النبي الأمي وعلى آله وصحبه عدد خلقه رضى نفسه و زنة عرشه و مداد كلماته وسلم

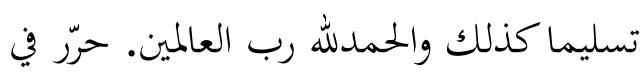
اليوم الثالث والعشرين من شهر المبارك رمضان من سنة ستة وثلثمائة وألف

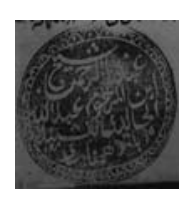


(Syekh Abdurrahman ibn al-Marhum 'Abd Allah al-Khalidi al-Naqshabandy Batu Hampari $1295 \mathrm{H})$

"Segala puji bagi Allah dengan pujian yang Ia ridhai untuk kesucian zatNya, serta shalawat dan salam semoga tercurahkan atas orang pilihanNya yang mulia untuk diberikan wahyu dan khitab Nya, khalifa Allah untuk segala khalifahNya yakni Sayyidina Muhammad, dan semoga tercurahkan juga kepada Keluarga dan sahabatnya. Setelah itu maka saya Abdurrahmân bin 'Abdullâh al-Khâlidî al-Naqsyabandi yang bermukim di Batu Hampar, sungguh telah aku ijazahkan anakku pada jalan Allah dan yang dia itu mencintai karena Allah lagi menuju kepada Allah yaitu Haji Muhammad Râsyidîn bin Maulaâna Abdurrahmân al-Jâwi Batu Hampar -mudah-mudahan Allah memberinya taufiq dan mencintainya dan meridhainya dan kesempurnaan atas sekalian orang Mukmin, Lalu memberi limpahan Allah kepadanya- dengan mengajarkan zikir dan tawajuh yang telah ditetapkan dalam tarekat yang tinggi yaitu Naqsyabandiyah al-Mujaddidiyah yang dinisbahkan kepada tempat zahirnya segala keajaiban dan sumber segala rahasia-rahasia dan makna-makna yaitu guru dari para Syekh yaitu Syekh Ahmad al-Fârûqî al-Sirhindî yang dikenal dengan Imam Rabbâni sang pembaharu pada seribu tahun yang kedua semoga disucikan rahasianya dan aku jadikan tangannya tanganku dan qabulnya qabulku, maka aku menjamin bagi orang yang melazimkan akan tarekat ini bahwa memperoleh ia akan sesuatu yang tidak meliputi dengannya akal segala orangyang berakal dan tak tergapai oleh ilmu segala Ulama, dan tidak hamba beri ijazah orang tersebut kecuali setelah memintak ijazah daripada sekalian orang-orang yang termasyhur yang telah disebutkan nama-nama mereka pada silsilah yang tinggi dan dengan istikharah sesuai syari'at Nabi. Maka hendaklah orang yang ingin tetap dengan tarekat yang tinggi dan sunnah sunniyah ini agar bergaul dengannya. Dan aku berwasiat kepadanya untuk berpegang teguh kepada al-Qur'an dan alSunnah, selanjutnya meluruskan akidah sesuai dengan paham Ahl al-Sunnah yang mana mereka itu adalah golongan yang selamat berdasarkan sesuatu yang telah di terapkan para Imam kasyaf dan wijdan dan aku berwasiat kepadanya dengan memuliakan para fuqaha dan fuqara dan para penghafal qur'an dan aku wasiatkan juga dengan berlapang dada dan ringan jiwa dan ringan tangan dan bermanis wajah dan pemurah dan menahan segala yang menyakitkan dan memaafkan kesalahan Taulan serta memberi nasehat kepada yang kecilkecil dan yang besar-besar dan meninggalkan berbantah-bantah, meninggalkan rakus, dan berpegang teguh kepada Allah azza wa jalla dalam menunaikan segala hajat, karena sesungguhnya dia tidak akan mensia-siakan orangyang memohonkan pertolongan kepadanya. Dan aku wasiatkan agar dia tidak mengharapkan keselamatan kecuali dalam kebenaran dan juga tidak mengharapkan sampai kepada Allah melainkan dalam mengikuti Nabi Muhammad semoga tercurabkan shalawat kepadanya, keluarga dan sahabatnya. Dan janganlah dirinya sekali-kali mengira lebih baik dari seseorang, akan tetapi dia tidak meliat dirinya itu ada. dan setiap orang yang menyakitinya dengan namimah dan hasad maka hendaklah dia menyerahkan urusannya kepada Allah dan tidak perlu memberatkan diri dalam menolak keburukan orang itu dengan himah. Maka sesungguhnya sebahagian dari guru-guru tarekat yang tinggi ini ada orang-orang yang dengan himmah mereka saja 
berlobanglah pegunungan, jika mau mereka mampu memindabkan benda yang rusak dengan takdir Allah secepat mungkin. Semoga Allah melimpahkan kesejahteraan dan keselamatan kepada Nabi yang ummi, keluarga, dan sahabatnya sebanyak bilangan makhluk, sekehendaknya, seindah 'arsynya sepanjang waktu. Segala puji bagi Allah Tuhan Semesta Alam. Selesai pada hari dua puluh tiga dari bulah Ramadhan yang diberkahi pada tahun 1306"

Naskah di atas merupakan ijazah yang diberikan kepada Syekh Abdurrahman Batu Hampa kepada anaknya Syekh Arsyad Batu hampa pada tahun $1301 \mathrm{H} / 1884 \mathrm{M}$. Dalam ijazah ini jelas dinyatakan bahwa salah satu ajaran zikir dan tawajuh yang diamalkan pada tarekat Naqsyabandiyah Khalidiyah adalah ajaran zikir dan tawajuh yang diadopsi dari tarekat Naqsyabandiyah Mujaddidiyah yang dinisbahkan kepada Syekh Ahmad al-Faruqi Sirhindi.

Kedua, naskah ijazah berbasa melayu dan aksara arab melayu yang berisikan nama orang yang diijazahkan tanpa sanad atau silsilah dan nama orang yang diijazahkan beserta dengan sanad atau silsilah tarekat, seperti di bawah ini :

\footnotetext{
"Bismi Allâh al-Rahmân al-Rahîm Adapun silsilah Thariqah Naqsyabandiyah Khâlidiyah maka hamba Allah yang hina faqir al-haqir al-Haj Muhammad Syarif di dalam Nagari Pasaman daerah Sungai Talang mengambil ijazah daripada akhînâ Maulanâ Sayyidi Syekh 'Abdurrahman ibn al-Marhum Sayyid Husain al-Khalidi Kuran al-Qâ'imîn fî maqâm Maulana Sayyid Syekh Ibrahim al-Khalidi Naqsyabandiyah Mujaddidiyah dârr al-amân bilâd al-Kumpulan daerah Koto Tuo, dia mengambil ijazah daripada Niniknya Maulana Sayyid Syekh Kabir al-Mukaram Syekhuna wa Murshidina Sayyid Syekh Ibrahim al-Khalidi Naqsyabandi Kumpulan dan beliau itu mengambil ijazah daripada Syekh Kabir al-Mukaram yaitu Sayyidi Syekh Abdullah Sulayman Afandi alKhalidi al-Ash'ari Naqsyabandi qaddasa Allâh sirrahu dan beliau itu mengambil ijazah daripada Syekh
}

Kabir al-Mukaram Maulana Dhiya'al-Dîn al-Syekh al-Khalidy qaddasa sirrahu dan beliau itu mengambil ijazah daripada Syekh Kabir al-Mukaram al-Syekh 'Abdullah al-Dah[la]wi qaddasa Allâhu sirrrahu dan beliau itu mengambil ijazah daripada Syekh Kabir al-Mukaram Syekh Samsudin qaddasa Allâhu sirrahu dan beliau mengambil ijazah daripada Syekh Kabir al-Mukaram Sayyidi Syekh Nur al-Badwani qaddasa Allâhu sirrahu dan beliau itu mengambil ijazah daripada Syekh Kabir al-Mukaram Maulana Syekh Muhammad Máshum qaddasa Allâhu sirrahu dan beliau mengambil ijazah daripada Syekh Kabir al-Mukaram al-Syekh Ahmad al-Faruqi qaddasa Allâhu sirrahu dan beliau itu mengambil ijazah daripada Syekh Kabir al-Mukaram Mu'yidin alSyekh Muhammad al-Baqi qaddasa Allah sirrahu dan beliau itu mengambil ijazah daripada Syekh Kabir al-Mukaram Maulana Syekh Khawajakan alAmkan al-Samarqandi qaddasa Allâhu sirrabu dan beliau itu mengambil ijazah daripada Syekh Kabir al-Mukaram Maulana Syekh Muhammad Darwis qaddasa Allâhu sirrahu dan beliau itu mengambil ijazah daripada Syekh Kabir al-Mukaram Syekh al-Masyayikh Maulana Syekh Muhammad Zabidi qaddasa Allâhu sirrahu dan beliau itu mengambil ijazah daripada Syekh Kabir al-Mukaram al-Masyrab al-Naqsyabandi al-Márufbikhawajihi Ahrari al-Syekh 'Abd Allah al-Sumarqandi qaddasa Allâbu sirrahu dan beliau itu mengambil ijazah daripada Syekh Kabir al-Mukaram Maulana al-Syekh Muhammad Yảqub al-Jarkhi al-H\{as\}ari qaddasa Allâhu sirrahu dan beliau itu mengambil ijazah daripada Syekh Kabir al-Mukaram Qatib al-Aqthab al-Syekh Mubs ammad Bukhari qaddasa Allâhu sirrabu dan beliau itu mengambil ijazah daripada Syekh Kabir al-Mukaram Daulah Imam al-Thariqah wa Ghauth al-Khalifah al-Faidh al-Jadi wa al-Nur al-asrar al-Maruf Bishah al-Naqsyabandi Syekh Baha' al-Din Muhammad alAusi al-Bukhari qaddasa Allâhu sirrahu dan beliau itu mengambil ijazah daripada Syekh Kabir al-Mukaram Jaulatu Mani al-Ma'araf al-Kamal Sayyid al-Sadat al-Syekh Sayyid Kilal qaddasa Allâhu sirrahu dan beliau itu mengambil ijazah daripada Syekh Kabir al-Mukaram qatib al-Auliya al-Syekh Baba al-Samasi qaddasa Allahbu sirrahu dan beliau itu mengambil ijazah daripada Syekh Kabir al-Mukaram al-Mairudh 'an al-Dunyawi wa al-Ukhrawi Syekh al-Mashaikh Muhammad al-Anjiri Fanawi qaddasa Allâhu sirrahu dan beliau itu mengambil ijazah daripada Syekh Kabir al-Mukaram Qatib al-Auliya' al-Syekh al-Arif al-Riyawukri qaddasa Allahu sirrahu dan beliau itu mengambil ijazah daripada Syekh Kabir al-Mukaram Qatib al-Rabbani al-Syekh 'Abd al-Khaliqi Fajwani qaddasa Allâhu sirrahu dan beliau itu mengambil ijazah daripada Syekh Kabir al-Mukaram Quwwatu 
al-Ghauthi al-Shamadani al-Syekh Yusufal-Hamdani qaddasa Allahbu sirrahu dan beliau itu mengambil daripada Syekh Kabir al-Mukaram Qatib al-Aqthab Syekh Abi Ali al faramidi qaddasa Allâhu sirrahu dan beliau itu mengambil ijazah daripada Syekh Kabir al-Mukaram Sulthan al-Arifin al-Syekh al-Ghauth al-Washilin al-Syekh Ibn al-Kharqani qaddasa Allâhu sirrahu dan beliau itu mengambil daripada Syekh Kabir al-Mukaram Sulthan al-Arifin Yazid al-Bisthami qaddasa Allâhu sirrahu dan beliau itu mengambil ijazah daripada Syekh Kabir al-Mukaram Syekh Imam Jafar Ibn Muhammad al-Shadiq Radhi Allâhu hu Anhuma dan beliau itu mengambil ijazah daripada Syekh Kabir al-Mukaram Syekh Qasim Ibn Abi Bakr al-Shiddiq Radhi Allahu Anhuma dan beliau itu mengambil ijazah daripada (daripada) Syekh Kabir al-Mukaram Syekh Salman al-Farisi Radhiy Allahu 'Anhu dan beliau itu mengambil ijazah daripada Ashhabah Rasulullah Shalallah Alaihi Wasallam Sayyina Abi Bakar Shiddiq Radhi Allah 'Anhu dan beliau itu mengambil ijazah daripada al-'Ulama' wa al-Mursalin al-Mahbub Rab al-Alamin Sayyidina Muhammadan al-Musthafa Shalallah Alaihi Wasallam dan ia mengambil daripada Sayyidina Jibrail 'Alaibi Salam yang ia mengambil daripada Tuhan Rab al'Alamin wa Shalallah Kathir Muhammad wa Alihi 'Adada Khalkihi wa Sallam Tasliman Mithlu Dzalik."

\section{Bismillâhirrahmânirrahîm}

Al-hamdulillâh hamdan yartadhîhi lijanâ bihi wa al-shalât wa al-sallâm 'ala ajalli man ishthafâ liwahyihi wa khithaâbihi khalifah Allâh fi khalîfatihi Muhammad wa 'ala 'âlihi wa ashhâbihi. Adapun kemudian daripada itu maka berkatalah hamba seorang yang Faqir ila Allah ta'ala bahwasanya telah hamba beri ijazah akan seorang saudara akhi pada jalan kepada Allah yaitu al-Mukaram al-Muhtaram yaitu al-Haj Muhammad Syarif di dalam Negri Pasaman Kampung Sungai Talang mudah-mudahan memberi Allah akan dia itu taufik bagi mengerjakan barangyang dikeridhai Allah ta'ala mudah-mudahan memberi limpah Allah ta'ala atas sekalian mukminin akan segala fayd-Nya dan berkatnya hamba ijazahkan akan dia pada mengerjakan zikir dan pada tawajjuh yang telah teradat pada tarekat Naqhabandiyah Mujadidiyah Khalidiyah yang dibangsakan kepada Imam yang menzahirkan segala yang ajaib-ajaib dan tempat terbit segala rahasia yaitu Syekh sekalilan Syekh Ahmad al-Faruqi al-Sirhindi yang telah dimasyhurkan dengan namanya Imam al-Rabbani yang membaharui Agama pada seribu tahun yang kedua hamba jadikan tangannya seperti tangan hamba dan qabulnya itu seperti qabul hamba sungguhpun bagi barang siapa melazimkan akan tarekat ini bahwa mendapat akan barang yang tiada meliputi dengan dia itu oleh akal segala mereka yang berakal dan pendek daripadanya ilmu segala Ulama dan tiada hamba beri ijazah akan al-Haj Muhammad Syarif yang tersebut itu melainkan kemudian daripada memintak ijazah daripada segala Auliya yang masyhur-masyhur yang tersebut nama mereka itu semu[h] anya di dalam do'a silsilah dan kemudian daripada hamba istikharah syar'iyah maka hendaklah berpegang dengan dia siapasiapa yang berkehendak bergantung kepada tarekat Naqsyabandiyah ini dan hamba pesan akan dia itu dengan berpegang dengan Kitâbullâh dan Sunnah Rasulullah Shalallah 'Alaihi wa Sallam dan hamba suruh akan dia dengan mehasilkan segala 'aqâ'idah al-imân dengan mazhab Ahl al-Sunnah wa al-Jama'ah karena mereka itu mempunyai keluasan daripada sesuatu seperti barang yang telah dilihat di dalam kasyafyang sahih oleh segala Aulia Allah ta'ala dan lagi usiat akan dia dengan memuliakan segala Ulama dan segala Fuqaha dan segala orang yang Hafizh Qur'an dan dengan suci hati daripada dengki dan kianat dan dengan murah tangan pada segala harta dan manis muka dan murah nafas pada segala jalan kebajikan dan sabar atas kesakitan dan memaafkan segala kesalahan taulan dan memuliakan segala mereka yang tuha-tuha dan kasihan kepada segala mereka yang muda-muda dan meninggalkan bertambah-tambah pada sekalian perkara istimewa pula cara i'tiqad dan menjaubkan tamak pada harta dan hendaklah berpegang pada menyampaikan barang mana hajah kepada Allah ta'ala dan janganlah harap akan sampai kepada Allah Ta'ala melainkan pada jalan yang benar dan pada mengikuti syari'at Rasulullah Shalallah Alayhi Wasallam pada zahir dan batin dan janganlah sekali-kali disangkanya dirinya itu afdhal daripada seorang jua daripada makhluk hanyalah hendaklah di itiqatkannya dirinya itu (tiada) maujud dan barang siapa menyakiti akan dia dengan hasad atau namimah atau barang sebagainya maka hendaklah diserabkan pekerjaannya itu kepada Allah Táala jua inilah usiat Ninik hamba Sayyidi Syekh Ibrahim al-Khalidi Naqsyabandi Kumpulan dan hamba usiatkan pula seperti demikian kepada orang yang memakai surat ini yang tersebut dahulu itu hendaklah diamalkan usiat hamba itu dan usiatkan pula kepada siapa-siapa mengikuti dia demikianlah adanya.

Muhararu fi yaumi sabt 28 Sawal sanah 1334 likitâbatihi al-Syekh 'Abd al-Rahman Ibn alMarhum Syekh Muhammad Husain al-Khalidi Kumpulan Kampung Padang

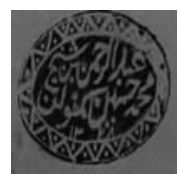


('Abd al-Rahman bin Syekh Muhammad Husain Kumpulan, 1328)

Pada ijazah ini jelas terlihat bahwa Syekh Abdurrahman yang merupakan khalifah dari Syekh Ibrahim Kumpulan memberikan ijazah kepada Muhammas Syarif melalui sanad atau silsilah Syekh Ibrahim Kumpulan yang mengambil tarekat kepada Syekh Abdullah Afandy seorang khalif dari Syekh Khalid Kurdi. Ini sekaligus menjadi bukti bahwa tarekat Naqsyabandiyah telah dikembangkan oleh Syekh Ibrahim Kumpulan sepulang dari Mekah dengan membawa ijazah mursyidnya. Hingga pernyataan Martin dan Schrieke yang mengatakan tarekat

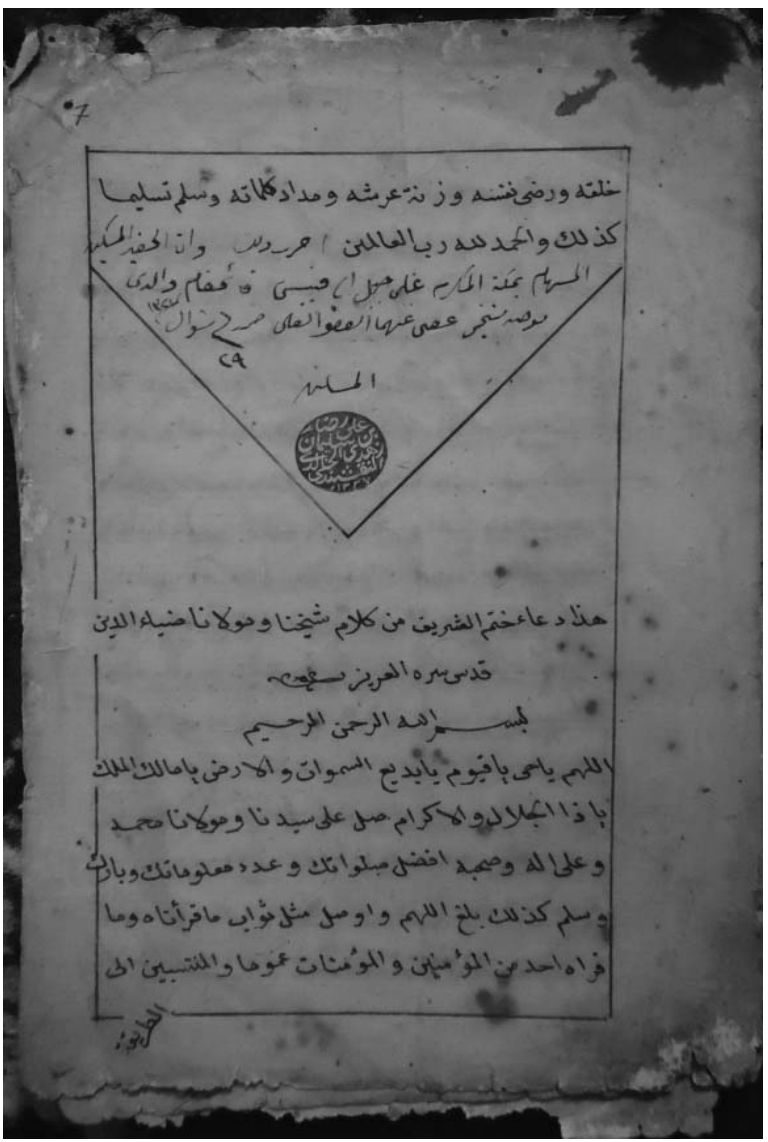

Naqsyabandiyah baru masuk pada tahun $1850 \mathrm{M}$ oleh Syekh Ismail dapat terbantahkan.

Ketiga, Naskah Ijazah berbahasa Arab yang berisikan nama orang yang diijazahkan serta silsilah tarekat Naqsyabandiyah milik mursyid yang memberi ijazah. Ijazah ini terdiri dari dua macam, yaitu: 1) Ijazah yang hanya menuliskan nama orang yang mengijazahkan dan yang menerima ijazah beserta wasiat dan silsilah tarekatnya; 2) Ijazah yang berisikan nama penerima ijazah dan pemberi ijazah serta wasiat dan silsilah tarekat, kemudian terdapa juga do'a khatam khawajakan pada ijazah tersebut. Contoh dari naskah ketiga ini dapat dilihat pada gambar berikut:

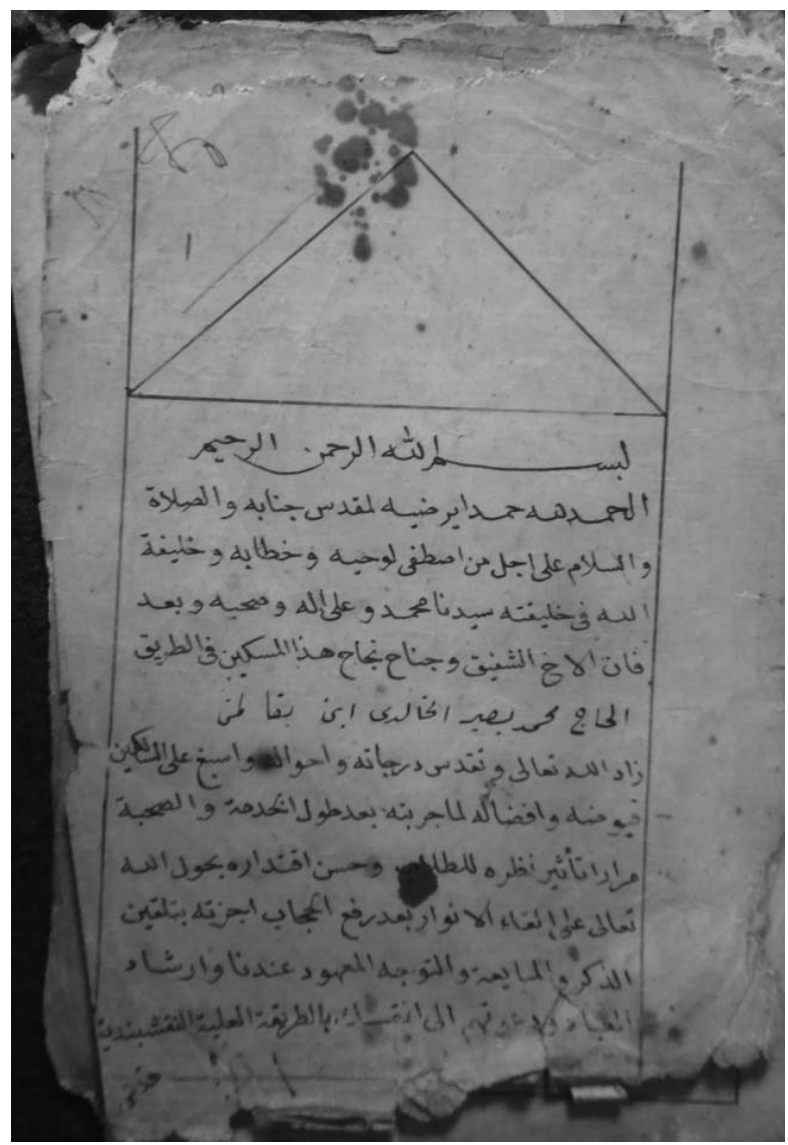

Foto Naskah dengan stempel Ali Ridha dan do'a khatam khawajakan 


\section{KESIMPULAN}

Tarekat Naqsyabandiyah sebagai tarekat yang mendominasi di Minangkabau bersumber dan berpusat di Jabal Abi Qubais berdasarkan Naskah Ijazha. Umumnya ijazah tarekat Naqsyabandiyah di Minangkabau untuk melalui genealogi Timur Tingah bersumber kepada Abdullah Afandy sebagai Khalifah Syekh Khalid dan Syekh Sulaiman Zuhdi sebagai khalifah dari Syekh Sulaiman al-Qarimi yang merupakan khalifah dari Syekh Abdullah Afandi. Sedangkan untuk genealogi di Minangkabau awal bersumber dari Syekh Ibrahim Kumpulan dan Syekh Ismail al-Minangkabawi. Kedua ulama ini mendapat ijazah dari Syekh Abdullah Afandi. Syekh Ismail ketika berada di Makkah memberikan ijazah kepada Syekh Abdurrahman dan Syekh Thaher Barulak yang kemudian sangat berjasa dalam perkembangan tarekat Naqsyabandiyah di Minangkabau.

Setiap ijazah yang digunakan oleh Syekh Ibrahim dan Syekh Abdurrahman Batu Hampa memiliki format dan isi yang sama, yang membedakannya hanyalah bahasa, untuk ijazah Syekh Abdurrahman berbahasa Arab dan untuk Ijazah Syekh Ibrahim berbahasa Melayu yang bisa dikatakan terjemahan dari ijazah berbahasa Arab. Ijazah ini tidak memiliki silsilah, hanya berisi nama pengijazah dan nama penerima ijazah beserta wasiat-wasiat. Sedangkan ijazah dari jalur Sulayman Zuhdi dan Ali Ridha milik Syekh Muhammad Bashir Lubuk Landur memiliki format dan isi yang berbeda. Pada ijazah ini tidak saja mengandung nama pemberi dan penerima ijazah namun juga terdapat silsilah tarekat dan doa khatam khawajakan.
Berdasarkan ini dapat dikatakan bahwa telah terjadi perubahan bentuk ijazah pada tarekat Naqsyabandiyah, dan dengan ini juga dapat kita kategorisasikan bahwa ijazah milik Syekh Abdurrahman Batu Hampa dan Syekh Ibrahim Kumpulan adalah bentuk ijazah awal atau tertua di Minangkabau. Ketika tarekat ini pertama kali berkembang bentuk ijazah inilah yang digunakam. Sedangkan bentuk ijazah milik Syekh Muhammad Bashir Lubuk Landur adalah bentuk ijazah yang telah dirubah formatnya ketika masa Syekh Sulaiman Zuhdi dan inilah yang digunakan setelah pertengahn abad ke 20 dimana tarekat Naqsyabandiyah telah tersebar luas. Selain itu, setiap ijazah diperkuat dengan stempel mursyid yang mengijazahkannya sebagai bukti bahwa ijazah ini original. Sehingga tidak gampang bagi orang lain untuk memalsukan ijazah.

\section{DAFTAR PUSTAKA}

Abdullah, Muhammad Shagir. (1985). Syekh Ismail al-Minangkabawi Penyiar Tarekat Naqsyabandiyah Khalidiyah. Solo: Ramadhani.

Ansari Muhammad, Abdul Haq. (1986). Sufism and Shari'ah: A Study of Shaykh Ahmad Sirhindi's Effort to Reform Sufism. Islamic Fondation.

Azra, Azyumardi. (2007). Jaringan Ulama Timur Tengah dan Kepulauan Nusantara Abad XVII dan XVIII. Jakarta: Kencana.

Bruinessen, Martin van. Tarekat Naqsyabandiyah di Indonesia. Bandung: Mizan, 1992. 
(1995). Kitab Kuning, Pesantren dan

Tarekat, Tradisi-tradisi Islam di Indonesia.

Bandung: Mizan.

Chambert-Loir, Henri. (2013). Naik Haji di Masa Silam, Kisah-kisah Orang Indonesia Naik Haji 1482-1964, jilid I. Jakarta: Kepustakaan Populer Gramedia (KPG).

Dipodjojo, S Asdi. (1996). Memperkirakan

Titimangsa Suatu Naskah. Yogyakarta: Lukman Ofset Yogyakarta.

Dobbin, Christine. (1992). Kebangkitan Islam Dalam Ekonomi Petani Yang Sedang Berubah,Sumatera Tengah, 1784-1847. Jakarta: INIS.

al-Dausari, Husein Ibnu Ahmad al Bishri al Khalidi. (1306). Rahmatul Habithah fi Zikri Ismu Dzat wa ar Rabithah. Makkah: al Muhamiyah.

al-Damshiqi al-Baythar, 'Abd al-Razaq. (1993). Hilyah al-Bashar fi Târikh al-Qarn al-Tsalits Ashr. Beirut: Dar Shadir.

Fathurahman, Oman. (2011). Filologi dan Islam Indonesia. Jakarta: Puslitbang Lektur Keagamaan Badan Litbang dan Diklat Kementrian Agama RI.

Forum Karya Ilmiyah (FKI) TAHTA Lirboyo. (2013). Kajian Pesantren Tradisi dan Adat Menjawab Vonis Bid'ah. Kediri: Gerbang Lama.

Foley, Sean. (2008). The NaqshabandiyyaKhalidiyya, Islamic Sainthood, and Religion in Modern Times. Journal of World History, Vol. 19, No. 4.
Hadi, Syofyan. (2011). Naskah al-Manhal al-adhb li-Dhikiral-Qalb: Kajian atas Dinamika Perkembangan Ajaran Tarekat Naqsyabandiyah Khalidiyah di Minangkabau. Lembaga Studi Islam Progresif (LSIP).

Hasan. (1333). Maqâmât Imâm Rabbânî, Mujaddid Alf Tsânî. Shahi Press.

Ismail, Taufiq. (1978). Sejarah dan Masyarakat. Jakarta: Pustaka Firdaus.

al-Kurdi, Muhammad Amin. (1996). al-Mawâhib al-Sarmadiyyah. Damsiq: Dar Hira. . (t.th). Tanwîr al-Qulûb fi Mu'âmalah al-Allâm al-Ghuyûb. Damsiq: Dar Ihya' alKutub al-'Arabiyyah.

Laffan, Michael. (2011). The Makings of Indonesian Islam: Orientalis and the Narration of a Sufi Past. Princeton University Press.

Mulyati, Sri. (2004). Mengenal dan Memahami Tarekat-Tarekat Muktabarah di Indonesia. Jakarta: Prenada Media.

al-Nabhani Ismail, Yusuf bin. (1978). Jâmi' Karâmati al-Awliyâ' (cet. III). Beirut: Maktabah al-Syabi'ah.

ar-Rasuly, Sulaiman. (1954). Tabligh al-Ämanât fi Izalati al-Munkarât wa al-Syubhât. Bukittinggi: Nusantara.

Schrieke. (1973). Pergolakan Agama di Sumatera Barat: Sebuah Sumbangan Bibliografi. Jakarta: Bhatara. 